\section{RSP}

http://www.rsp.fsp.usp.br/
Revista de Saúde Pública

\title{
Use of medicines by patients of the primary health care of the Brazilian Unified Health System
}

\author{
Clarisse Melo Franco Neves Costa', Micheline Rosa Silveira", Francisco de Assis Acurcio", Augusto \\ Afonso Guerra Junior", Ione Aquemi Guibu" ${ }^{\prime \prime \prime}$, Karen Sarmento Costa ${ }^{\mathrm{IV}, \mathrm{V}, \mathrm{VI}}$, Margô Gomes de \\ Oliveira Karnikowski ${ }^{\mathrm{VII}}$, Orlando Mario Soeiro ${ }^{\mathrm{VIII}}$, Silvana Nair Leite ${ }^{\mathrm{IX}}$, Ediná Alves Costa ${ }^{\mathrm{X}}$, Renata \\ Cristina Rezende Macedo do Nascimento', Vânia Eloísa de Araújo ${ }^{\mathrm{XI}}$, Juliana Álvares" \\ ' Programa de Pós-Graduação em Medicamentos e Assistência Farmacêutica. Faculdade de Farmácia. \\ Universidade Federal de Minas Gerais. Belo Horizonte, MG, Brasil \\ " Departamento de Farmácia Social. Faculdade de Farmácia. Universidade Federal de Minas Gerais. Belo \\ Horizonte, MG, Brasil \\ III Faculdade de Ciências Médicas. Santa Casa de São Paulo. São Paulo, SP, Brasil \\ Iv Núcleo de Estudos de Políticas Públicas. Universidade Estadual de Campinas. Campinas, SP, Brasil \\ $\checkmark$ Programa de Pós-Graduação em Saúde Coletiva. Departamento de Saúde Coletiva. Faculdade de Ciências \\ Médicas. Universidade Estadual de Campinas. Campinas, SP, Brasil \\ vı Programa de Pós-Graduação em Epidemiologia. Faculdade de Medicina. Universidade Federal do Rio Grande \\ do Sul. Porto Alegre, RS, Brasil \\ VII Faculdade de Ceilândia. Universidade de Brasília. Brasília, DF, Brasil \\ VIII Faculdade de Ciências Farmacêuticas. Pontifícia Universidade Católica de Campinas. Campinas, SP, Brasil \\ Ix Departamento de Ciências Farmacêuticas. Universidade Federal de Santa Catarina, Florianópolis, SC, Brasil \\ $x$ Instituto de Saúde Coletiva. Universidade Federal da Bahia. Salvador, BA, Brasil \\ xI Instituto de Ciências Biológicas da Saúde. Pontifícia Universidade Católica de Minas Gerais. Belo Horizonte, MG, Brasil
}

Correspondence/Email:

Micheline Rosa Silveira Faculdade de Farmácia,

Universidade Federal de Minas Gerais

Av. Presidente Antônio Carlos, 6627

- sala 3012

Campus Pampulha 31270-901

Belo Horizonte, MG, Brasil

E-mail: michelinerosa@gmail.com

Received: Jul 04, 2016

Approved: Jan 17, 2017

How to cite: Costa CMFN, Silveira MR Guerra Junior AA, Costa EAII, Acurcio FAII, Guibu IAIII, et al. Use of medicines by patients of the primary health care of the Brazilian Unified Health System. Rev Saude Publica. 2017;51 Suppl 2:18s.

Copyright: This is an open-access article distributed under the terms of the Creative Commons Attribution License, which permits unrestricted use, distribution, and reproduction in any medium, provided that the original author and source are credited.

\section{ABSTRACT}

OBJECTIVE: To characterize the use of medicines by patients of the primary health care of the Brazilian Unified Health System (SUS).

METHODS: This is a cross-sectional, exploratory, and descriptive study, part of the Pesquisa Nacional sobre Acesso, Utilização e Promoção do Uso Racional de Medicamentos - Serviços, 2015 (PNAUM - National Survey on Access, Use and Promotion of Rational Use of Medicines - Services, 2015). Interviews were carried out with patients present in the services by semi-structured questionnaires. Sociodemographic, clinical, and use of medicines variables were assessed and the use of medicines in the 30 days prior to the interview was also verified. The population was stratified into three age groups: 18 to 44,45 to 64 , and 65 years or more. The differences between the age groups were verified using the Student's t-test for continuous variables and chi-square test for the categorical ones. The complex samples analysis plan was employed. The medicines were classified according to the Anatomical Therapeutic Chemical Classification System.

RESULTS: Of the 8,803 patients interviewed, 6,511 (76.2\%) reported to have used medicines in the 30 days prior to the interview. On average, each patient used 2.32 medicines, without difference between the sexes. Among medicine users, $18.2 \%$ were aged 65 years or more. Compared to the other age groups, older adults presented more comorbidities, used more medicines, and self-reported worse health conditions. They were also less educated, reported worse economic situation, and lived alone. The medicines that were mostly used were "other analgesics and antipyretics" ( $3^{\text {rd }}$ ATC level) and Losartan ( $5^{\text {th }}$ ATC level).

CONCLUSIONS: Most medicine users had lower education level and presented comorbidities. The most used medicines were the antihypertensive ones. Self-medication was higher among young people. Most patients reported to use generic medicines. The average number of medicines and the prevalence of use increased with age. Due to the characteristics observed and the difficulties in the use of medicines, older adults are in a situation of greater vulnerability.

DESCRIPTORS: Drug Utilization. Pharmacoepidemiology. Pharmaceutical Services. Primary Health Care. Health Services Research. Unified Health System. 


\section{INTRODUCTION}

Medicines have assumed an important role in reducing human suffering. They produce healing, prolong life, and delay the emergence of complications associated with the disease, thus facilitating the coexistence of the individual with his/her illness. Furthermore, medicines are considered highly cost-effective technologies and their proper use can influence the process of health care ${ }^{20}$.

The use of medicines is influenced by the demographic structure, socioeconomic, behavioral, and cultural factors, morbidity profile, characteristics of the pharmaceutical market, and Government policies directed to the sector ${ }^{16}$. The wide range of products, the pharmaceutical industry marketing, and the number of prescribed medicines are factors that can compromise the quality of the use of medicines ${ }^{18}$.

The increased prevalence of chronic diseases in the Country, especially arterial hypertension, diabetes, arthritis/osteoarthritis, and depression is a result of the rapid and growing process of ageing of the Brazilian population in recent years. In parallel with this process, the use of medicines is growing, necessary to control and prevent problems related to the health of individuals ${ }^{19}$.

According to data from the World Health Organization (WHO) over $50 \%$ of the medicines are prescribed or dispensed inappropriately all around the world, and about $50 \%$ of patients use medicines incorrectly, leading to high indexes of morbidity and mortality. The misuse of medicines is also related to the use of multiple medicines, inappropriate use of antibiotics and injectable medicines, self-medication, and prescriptions that do not comply with clinical guidelines ${ }^{a}$.

Primary health care (PHC), as part and coordinator of a health care network, must be prepared to solve almost all of the most common problems that arise in the context of primary health care. Completeness means the provision, by the health team, of a set of services that meet the needs of the population in the fields of promotion, prevention, cure, care, and rehabilitation. Access to medicines with quality and the promotion of their correct and timely use contributes to a resolutive $\mathrm{PHC}^{14}$.

The importance of medicines in health care is growing, either from an economic point of view or from the health point of view. The expansion of the population's access to health care, by SUS, demanded, over the past years, changes in the organization of public Pharmaceutical Services (PS), to increase the coverage of free distribution of medicines, as well as the construction of a legal framework to support the process of decentralization of the management of PS actions ${ }^{15}$.

From the analysis of the consumption of medicines and of PS, it is possible to qualify the use of medicines, improving individual and collective health conditions, as well as deploying preventive or healing actions 9 .

The Pesquisa Nacional sobre Acesso, Utilização e Uso Racional de Medicamentos - Serviços (PNAUM - National Survey on Access, Use and Promotion of Rational Use of Medicines Services) aimed at characterizing the coordination of pharmaceutical services in SUS primary health care to promote access and rational use of medicines, as well as identifying and discussing the factors that affect the consolidation of pharmaceutical services in the cities. In this context, this study aimed to characterize the profile of use of medicines by patients of SUS primary health care.

${ }^{a}$ World Health Organization, Quality Assurance and Safety of Medicines Team. The safety of medicines in public health programmes: pharmacovigilance an essential tool. Geneva: WHO; 2006 [cited 2016 Mar 4]. Available from: http://apps.who. int/iris/bitstream/10665/43384 /1/9241593911_eng.pdf

\section{METHODS}

PNAUM is a cross-sectional, exploratory, evaluative study, consisting of information collection in a representative sample of primary health care services, in cities of the Brazilian regions. Face-to-face interviews were carried out with patients, physicians, and professionals responsible for the dispensing of medicines in the primary health care services of SUS. The 
study was comprised of various populations, with stratified samples by region. We opted for the use of sampling in various stages of selection, in each stage the populations were sampled and the estimates relating to them were made separately. Three samples were drawn: of cities, services, and patients. In the first, the cities were elements of the sample. In the second, these cities became primary sampling units, in which the services that composed the sample were drawn. In the third, the services became secondary sampling units, in which the patients (which are the focus of this study) were drawn. The PNAUM - Services methodology, as well as the sampling process, are described in detail by Álvares et al. (2016)1.

To characterize the profile of use of medicines, data from the interviews with the patients present in the PHC services were used. The use of medicines in the 30 days prior to the interview was verified. Sociodemographic, clinical, and medicine use (use of generic medicines, self-medication, need of help to use the medicines, medicines used, and use of the Programa Farmácia Popular (PFP - Popular Pharmacy Program)) variables were assessed.

The medicines were classified in therapeutic categories, by their active ingredient, according to the Anatomical Therapeutic Chemical Classification System (ATC). In this system, the substance is classified according to the organ or system on which it acts and to their chemical, pharmacological, and therapeutic properties. The medicines are divided in 14 main groups ( $1^{\text {st }}$ level), with pharmacological/therapeutic subgroups $\left(2^{\text {nd }}\right.$ level $)$. The $3^{\text {rd }}$ and $4^{\text {th }}$ levels correspond to chemical/pharmacological/therapeutic subgroups, and the $5^{\text {th }}$ level to the chemical substance ${ }^{26}$.

Medicines of the following classes were classified as antihypertensive: antihypertensive (C02), diuretics (C03), beta blockers (C07), calcium channel blockers (C08), and agents acting in the renin-angiotensin system (C09). As antidiabetic, medicines used in diabetes (A10) were employed, and as antidepressants, the psycholeptics (N05) and psychoanaleptics (N06). Medicines for dyslipidemia were lipid modifiers agents (C10) and anti-obesity preparations, excluding dietetic products (A08). As there is no specific protocol for arthritis, osteoarthritis, and rheumatism, for these diseases the medicines considered were: corticosteroid medicines for simples systemic use (A07E), nonsteroidal and antirheumatic anti-inflammatory products (C01E), simple corticosteroids (D07A), corticosteroids for simple systemic use (H02A), immunosuppressants (L04A), nonsteroidal and antirheumatic anti-inflammatory products (M01A), other analgesics and antipyretics (N02B), and antimalarial medicines (P01B).

The relationship between the report of medical diagnosis of the most prevalent diseases and the use of medicines indicated for the treatment of these diseases was also assessed. The population was stratified into three age groups: 18 to 44,45 to 64 , and 65 years or more. The differences among the age groups were verified using the Student's t-test for continuous variables and Pearson's chi-square test for the categorical ones.

Data analysis was performed using the plan of complex samples of the SPSS software version 22.

PNAUM was approved by the National Research Ethics Committee of the National Health Council, under Opinion no. 398,131/2013. All participants signed the informed consent form.

\section{RESULTS}

A total of 8,803 patients were interviewed in 1,305 PHC services, located in 272 cities distributed in the five regions of Brazil. Of these, 6,511 patients (76.2\%) reported having used medicines in the 30 days prior to the interview.

The average number of medicines used was 2.32 (95\%CI: 2.186-2.554) per patient. The average for each age group varied significantly: 1.75 (95\%CI: 1.65-1.85) for the age group of 18 to 44 years; 2.63 (95\%CI: $2.45-2.81$ ) for the 45 to 64 years age group; and 3.00 (95\%CI: $2.74-3.25$ ) for older adults ( 65 years or more). The prevalence of use of medicines increased according to the age group, being of $92.1 \%$ in persons aged 65 years or more. 
There was a predominance of the female sex in the population that uses medicines, but the proportion of men increased as age increased, being $36.1 \%$ in the age group of 65 years or more. No differences were found in the use of medicines among the sexes. Most medicine users had some elementary school (43.2\%) and only $3 \%$ reported to have a higher education degree. We observed the lowest education level among older adults, with a proportion of $26.5 \%$ of illiterate individuals. The majority of interviewed medicine users declared marital status married. Among older adults, $33.5 \%$ were widowers or divorced, with statistically significant differences compared to the other age groups. Regarding economic classification, most were from the economic class $\mathrm{C}$, and, among the older adults, the classes $\mathrm{D}$ and $\mathrm{E}$ prevailed (Table 1).

Most medicine users reported having one or more chronic diseases (77.6\%), with a statistically significant difference among the age groups $(\mathrm{p}<0.001)$, and among the older adults the prevalence was of $96.9 \%$. Among the major chronic diseases reported, hypertension was the most prevalent (48.9\%). Hypertension, hyperlipidemia, arthritis/osteoarthritis or rheumatism, diabetes mellitus, heart disease, and stroke were more prevalent among older adults and the difference was significant among the age groups $(\mathrm{p}<0.001)$.

Table 1. Sociodemographic and health characteristics of patients of the Primary Health Care of the Brazilian Unified Health System. National Survey on Access, Use and Promotion of Rational Use of Medicines - Services, 2015.

\begin{tabular}{|c|c|c|c|c|c|c|c|}
\hline \multirow{4}{*}{ Variable } & \multicolumn{6}{|c|}{ Age group (years) } & \multirow{4}{*}{ p } \\
\hline & \multirow{2}{*}{\multicolumn{2}{|c|}{$\begin{array}{c}18 \text { to } 44 \\
n=2,871\end{array}$}} & \multirow{2}{*}{\multicolumn{2}{|c|}{$\begin{array}{c}45 \text { to } 64 \\
n=2,499\end{array}$}} & \multirow{2}{*}{\multicolumn{2}{|c|}{$\begin{array}{c}65 \text { or more } \\
n=1,087\end{array}$}} & \\
\hline & & & & & & & \\
\hline & n* & $\%(95 \% \mathrm{Cl})$ & $\mathrm{n}^{*}$ & $\%(95 \% \mathrm{Cl})$ & n* & $\%(95 \% \mathrm{Cl})$ & \\
\hline Sex & & & & & & & $<0.001$ \\
\hline Female & 2,369 & $82.1(79.8-84.2)$ & 1,890 & $75.8(73.3-78.1)$ & 719 & $63.9(60.3-67.3)$ & \\
\hline Male & 502 & $17.9(15.8-20.2)$ & 609 & $24.2(21.9-26.7)$ & 368 & $36.1(32.7-39.7)$ & \\
\hline Marital status & & & & & & & $<0.001$ \\
\hline Married/Common-law marriage & 1,813 & $65.7(63.1-68.3)$ & 1,596 & $68.2(65.4-70.8)$ & 590 & $59.6(55.1-63.9)$ & \\
\hline Single & 950 & $30.2(28.0-32.6)$ & 400 & $12.5(10.8-14.3)$ & 89 & $7.0(5.3-9.0)$ & \\
\hline Other & 108 & $4.0(3.2-5.1)$ & 503 & $19.3(17.1-21.8)$ & 408 & $33.5(29.6-37.6)$ & \\
\hline Education level & & & & & & & $<0.001$ \\
\hline Illiterate & 71 & $3.2(2.2-4.6)$ & 293 & $12.9(10.1-16.6)$ & 278 & $26.5(19.9-34.2)$ & \\
\hline Some Elementary School & 710 & $28.8(26.0-31.8)$ & 1,186 & $50.9(46.7-55.0)$ & 598 & $59.6(50.8-67.8)$ & \\
\hline Elementary School & 731 & $24.3(21.5-27.2)$ & 467 & $17.9(15.6-20.6)$ & 110 & $8.6(5.5-13.2)$ & \\
\hline High School & 1,237 & $39.3(36.5-42.1)$ & 474 & $16.1(14.0-18.4)$ & 81 & $3.8(2.5-5.8)$ & \\
\hline Higher Education & 122 & $4.4(3.4-5.8)$ & 79 & $2.3(1.6-3.2)$ & 20 & $1.5(0.8-2.8)$ & \\
\hline Economic class & & & & & & & $<0.001$ \\
\hline$A$ and $B$ & 556 & $18.9(15.9-22.2)$ & 397 & $14.5(12.1-17.4)$ & 105 & $7.9(5.8-10.5)$ & \\
\hline $\mathrm{C}$ & 1,803 & $59.1(56.2-61.9)$ & 1,417 & $53.7(49.7-57.6)$ & 545 & $45.9(40.5-51.4)$ & \\
\hline $\mathrm{D}$ and $\mathrm{E}$ & 509 & $22.1(18.3-26.4)$ & 684 & $31.8(26.5-37.6)$ & 437 & $46.2(39.6-52.9)$ & \\
\hline Number of chronic diseases & & & & & & & $<0.001$ \\
\hline None & 1,309 & $43.6(40.4-46.9)$ & 213 & $7.9(6.7-9.4)$ & 34 & $3.1(2.0-4.9)$ & \\
\hline One & 836 & $30.6(28.1-33.2)$ & 589 & $26.2(23.1-29.5)$ & 227 & $21.6(18.2-25.3)$ & \\
\hline Two or more & 646 & $25.8(22.9-28.9)$ & 1,546 & $65.9(62.1-69.4)$ & 775 & $75.3(71.0-79.2)$ & \\
\hline \multicolumn{8}{|l|}{ Main chronic diseases } \\
\hline Hypertension & 551 & $22.0(19.4-24.9)$ & 1,513 & $62.3(58.9-65.5)$ & 872 & $81.7(77.7-85.2)$ & \\
\hline Dyslipidemia & 329 & $11.0(9.5-12.8)$ & 966 & $39.8(36.6-43.1)$ & 443 & $40.9(36.9-45.1)$ & \\
\hline Arthritis, osteoarthritis, or rheumatism & 234 & $8.2(6.7-10.1)$ & 800 & $32.4(28.7-36.3)$ & 457 & $40.6(35.4-46.2)$ & $<0.001$ \\
\hline Depression & 456 & $19.0(16.7-21.4)$ & 665 & $26.7(22.8-31.0)$ & 216 & $19.9(15.5-25.2)$ & \\
\hline Diabetes mellitus & 129 & $4.1(3.1-5.4)$ & 618 & $24.8(22.3-27.6)$ & 329 & $31.3(27.2-35.8)$ & \\
\hline Chronic lung disease & 325 & $11.5(9.8-13.6)$ & 282 & $9.9(8.2-11.8)$ & 120 & $10.0(7.4-13.4)$ & 0.321 \\
\hline Heart diseases & 103 & $3.6(2.7-4.8)$ & 269 & $11.1(8.9-13.8)$ & 224 & $20.8(16.6-25.8)$ & $<0001$ \\
\hline Cerebrovascular accident & 26 & $1.0(0.6-1.6)$ & 100 & $3.8(2.8-5.2)$ & 74 & $6.5(4.5-9.4)$ & $<0.001$ \\
\hline Regions & & & & & & & $<0.001$ \\
\hline North & 608 & $6.8(5.2-8.7)$ & 344 & $4.1(3.0-5.7)$ & 126 & $3.0(2.0-4.6)$ & \\
\hline Northeast & 552 & $31.9(24.4-40.5)$ & 443 & $25.7(18.4-34.7)$ & 207 & $28.8(19.6-40.2)$ & \\
\hline Midwest & 500 & $6.3(4.4-8.9)$ & 408 & $5.0(3.4-7.3)$ & 180 & $4.8(3.1-7.4)$ & \\
\hline Southeast & 564 & $29.4(22.8-37.0)$ & 597 & $36.4(27.9-45.9)$ & 249 & $36.9(25.0-50.8)$ & \\
\hline South & 647 & $25.7(19.3-33.3)$ & 707 & $28.8(21.4-37.6)$ & 325 & $26.4(17.9-37.3)$ & \\
\hline
\end{tabular}

Source: PNAUM - Services, 2015.

* Non-weighted $n$ value 
Regarding the need for help from another person to use the medicines, we observed greater proportions among older adults, $10 \%$ of which always need it and $4.4 \%$ sometimes.

Self-medication was higher among younger people (45.7\%) with a statistically significant difference $(p<0.001)$ per age group. Among the reasons for self-medication, the most reported were "previous use of the medicine" and "having it at home."

When non-use of medicines prescribed by the physician was investigated, higher proportions were observed in users in the 18 to 44 years age group (16.7\%). Among the reasons for this non-use stood out negative experience with the use of the same product (50.7\%), believing to already be healed (49.3\%) and considering that it was not necessary to use the medicine (46.1\%). For the age group of 65 years or more, the main reasons for non-use of the medicine were believing that the medicine is not correct or does not work (49.4\%) and previous negative experience (having used the medicine in the past and feeling sick because of it) (49.2\%).

More than half (57.8\%) of patients reported using generic medicines, but there was no significant difference between the age groups (Table 2). Concerning the Popular Pharmacy Program, the highest use was in the age group of 65 years or more (67.8\%), followed by 45 to 64 years $(63.8 \%)$ and 18 to $44(49.0 \%)$.

Of the 15,061 medicines reported by patients, it was possible to identify properly 13,515 items, which were classified considering the $5^{\text {th }}$ ATC level. Among the self-reported products, 1,546 $(9.3 \%)$ were described inappropriately, such as "I do not remember the name," "maleate," "cancer bacteria," "sulfuric acid."

Table 2. Characteristics of the use of medicines by patients of the Primary Health Care of the Brazilian Unified Health System. National Survey on Access. Use and Promotion of Rational Use of Medicines - Services, 2015.

\begin{tabular}{|c|c|c|c|c|c|c|c|}
\hline \multirow{4}{*}{ Variable } & \multicolumn{6}{|c|}{ Age group (years) } & \multirow{4}{*}{$\mathbf{p}$} \\
\hline & \multirow{2}{*}{\multicolumn{2}{|c|}{$\begin{array}{c}18 \text { to } 44 \\
\mathrm{n}=2.871\end{array}$}} & \multirow{2}{*}{\multicolumn{2}{|c|}{$\begin{array}{c}45 \text { to } 64 \\
\mathrm{n}=2.499\end{array}$}} & \multirow{2}{*}{\multicolumn{2}{|c|}{$\begin{array}{l}65 \text { or more } \\
n=1.087\end{array}$}} & \\
\hline & & & & & & & \\
\hline & $\mathrm{n}^{*}$ & $\%(95 \% \mathrm{Cl})$ & $\mathrm{n}^{*}$ & $\%(95 \% \mathrm{Cl})$ & $\mathrm{n}^{*}$ & $\%(95 \% \mathrm{Cl})$ & \\
\hline Do you use a generic medicine? & & & & & & & 0.375 \\
\hline Yes & 1.606 & $55.8(49.1-62.3)$ & 1.518 & $58.1(50.9-65.0)$ & 714 & $62.0(49.9-72.8)$ & \\
\hline No & 891 & $30.3(23.9-37.5)$ & 652 & $29.6(22.3-38.2)$ & 240 & $27.2(16.2-41.9)$ & \\
\hline Does not know & 373 & $13.9(10.3-18.5)$ & 329 & $12.2(9.3-16.0)$ & 133 & $10.8(7.5-15.2)$ & \\
\hline Do you need help to use the medicines? & & & & & & & $<0.001$ \\
\hline Always & 90 & $4.2(2.7-6.6)$ & 94 & $4.7(3.2-6.7)$ & 94 & $10.0(7.4-13.5)$ & \\
\hline Sometimes & 59 & $2.1(1.4-3.2)$ & 86 & $3.6(2.5-5.1)$ & 50 & $4.4(3.0-6.6)$ & \\
\hline No & 2.721 & $93.6(91.2-95.4)$ & 2.318 & $91.8(88.9-94.0)$ & 943 & $85.5(81.5-88.8)$ & \\
\hline Use of medicines without prescription (yes) & 1.392 & $45.7(41.6-49.8)$ & 930 & $36.5(32.1-41.1)$ & 283 & $27.8(22.9-33.3)$ & $<0.001$ \\
\hline \multicolumn{8}{|l|}{ Situations in which you use medicines without prescription } \\
\hline Previous use & 1.250 & $88.3(84.2-91.5)$ & 781 & $83.3(76.8-88.3)$ & 236 & $85.9(79.1-90.8)$ & 0.193 \\
\hline When you have the medicine at home & 1.150 & $82.4(73.7-88.7)$ & 741 & $81.7(72.1-88.5)$ & 208 & $77.0(62.4-87.1)$ & 0.242 \\
\hline Indication in the pharmacy & 1.037 & $71.4(66.8-75.7)$ & 577 & $60.8(53.7-67.5)$ & 156 & $51.8(44.8-58.8)$ & $<0.001$ \\
\hline Knows someone who has already used it & 831 & $56.9(51.2-62.4)$ & 473 & $48.9(42.5-55.5)$ & 136 & $42.8(34.9-51.0)$ & 0.002 \\
\hline Easy access to the medicine & 763 & $55.4(47.7-62.9)$ & 434 & $46.6(38.6-54.8)$ & 129 & $46.1(33.8-58.9)$ & 0.032 \\
\hline Read the consumer leaflet or other information & 685 & $47.1(42.3-52.0)$ & 326 & $34.5(28.7-40.7)$ & 58 & $18.1(12.5-25.4)$ & $<0.001$ \\
\hline Ceases to use medicines prescribed by the physician (yes) & 539 & $16.7(14.3-19.4)$ & 389 & $14.1(11.6-17.0)$ & 110 & $9.1(6.2-13.1)$ & 0.001 \\
\hline \multicolumn{8}{|l|}{ Cases in which you cease to use the prescribed medicines } \\
\hline Used before and felt sick & 326 & $50.7(42.1-59.2)$ & 224 & $47.9(38.1-57.9)$ & 62 & $49.2(34.7-63.9)$ & 0.741 \\
\hline $\begin{array}{l}\text { Considers that it is not the right one or that it does } \\
\text { not work }\end{array}$ & 284 & $46.2(38.2-54.4)$ & 201 & $45.5(36.7-54.6)$ & 57 & $49.4(37.7-61.2)$ & 0.844 \\
\hline Thinks it is too strong or weak & 276 & $44.3(38.0-50.8)$ & 164 & $39.0(30.4-48.3)$ & 40 & $32.0(22.4-43.4)$ & 0.396 \\
\hline Believes to be cured & 282 & $49.3(42.4-56.3)$ & 152 & $40.2(32.5-48.4)$ & 39 & $34.9(25.5-45.6)$ & 0.046 \\
\hline Evaluates that it is not needed & 267 & $46.1(39.4-53.1)$ & 160 & $40.7(32.9-48.9)$ & 39 & $32.4(21.0-46.3)$ & 0.043 \\
\hline $\begin{array}{l}\text { When you read something considered bad in the } \\
\text { consumer leaflet }\end{array}$ & 175 & $26.4(20.9-32.7)$ & 96 & $21.4(16.2-27.7)$ & 17 & $9.2(4.2-19.1)$ & 0.002 \\
\hline Uses the Brazilian Popular Pharmacy Program (yes) & 891 & $49.0(42.2-55.8)$ & 1.202 & $63.8(58.9-68.4)$ & 561 & $67.8(59.4-75.1)$ & $<0.001$ \\
\hline
\end{tabular}

Source: PNAUM - Services, 2015

* Non-weighted $\mathrm{n}$ value 
Table 3 presents the most used medicine groups, considering the $3^{\text {rd }}$ ATC level. Of the total of medicines, 1,249 (8.1\%) were classified as "other analgesics and antipyretics"; 819 (5.6\%), "hypoglycemic medicines, excluding insulin”; and 765 (5.5\%), "nonsteroidal and antirheumatic anti-inflammatory products."

Regarding the classification in the $5^{\text {th }}$ ATC level, the most used were: Losartan (4.8\%), simvastatin (4.1\%), omeprazole (3.9\%), hydrochlorothiazide (3.4\%), and metformin (3.2\%) (Table 4).

Among the respondents who reported having chronic diseases, $77.7 \%$ of those with hypertension and $62.1 \%$ of those with diabetes used specific medicines for the disease. Among the patients with dyslipidemia, arthritis, osteoarthritis or rheumatism, and depression, the majority did not report use of specific medicines for these diseases (Table 5).

Table 3. Medicines most used by patients of the Primary Health Care of the Brazilian Unified Health System, considering the 3rd Anatomical Therapeutic Chemical level. National Survey on Access, Use and Promotion of Rational Use of Medicines - Services, 2015.

\begin{tabular}{|c|c|c|c|}
\hline Pharmacological subgroup ( ${ }^{\text {rd }}$ ATC level) & ATC Code & n* & $\%(95 \% \mathrm{CI})$ \\
\hline Other analgesics and antipyretics & N02B & 1,249 & $8.1(6.8-9.7)$ \\
\hline Hypoglycemic medicines, excluding insulin & $\mathrm{A} 10 \mathrm{~B}$ & 819 & $5.6(5.1-6.3)$ \\
\hline Nonsteroidal and antirheumatic anti-inflammatory products & M01A & 765 & $5.5(4.9-6.3)$ \\
\hline Angiotensin-converting enzyme inhibitors & C09A & 824 & $5.2(4.5-6.1)$ \\
\hline Angiotensin II antagonists & C09C & 756 & $4.9(3.9-6.2)$ \\
\hline Antidepressants & N06A & 645 & $4.8(4.3-5.5)$ \\
\hline Hypolipidemic agents & C10A & 658 & $4.7(4.1-5.3)$ \\
\hline Medicines for peptic ulcer and gastroesophageal reflux disease & A02B & 640 & $4.4(3.9-4.9)$ \\
\hline Beta blockers agents & C07A & 615 & $4.2(3.6-5.0)$ \\
\hline Low power diuretics & $\mathrm{C} 03 \mathrm{~A}$ & 619 & $3.8(3.2-4.6)$ \\
\hline Antiepileptics & N03A & 427 & $3.0(2.6-3.5)$ \\
\hline Angiotensin-converting enzyme inhibitors, associations & C09B & 321 & $2.5(1.9-3.3)$ \\
\hline Centrally acting muscle relaxants & M03B & 378 & $2.5(2.0-3.0)$ \\
\hline Hormonal contraceptives for systemic use & G03A & 338 & $2.2(1.7-2.9)$ \\
\hline Antithrombotic agents & B01A & 262 & $1.9(1.5-2.3)$ \\
\hline Thyroid preparations & $\mathrm{H} 03 \mathrm{~A}$ & 256 & $1.8(1.5-2.2)$ \\
\hline Anxiolytics medicines & N05B & 224 & $1.8(1.4-2.3)$ \\
\hline Iron preparations & B03A & 337 & $1.8(1.4-2.1)$ \\
\hline Calcium channel selective blockers & C08C & 223 & $1.3(1.0-1.7)$ \\
\hline Beta-lactams antibacterials, penicillins & J01C & 215 & $1.3(1.1-1.6)$ \\
\hline
\end{tabular}

Source: PNAUM - Services, 2015.

* Non-weighted $\mathrm{n}$ value

Table 4. Medicines most used by patients of the Primary Health Care of the Brazilian Unified Health System, considering the 5th Anatomical Therapeutic Chemical level. National Survey on Access, Use and Promotion of Rational Use of Medicines - Services, 2015.

\begin{tabular}{|c|c|c|c|}
\hline Name of the medicine & ATC Code & $n^{a}$ & $\%(95 \% \mathrm{CI})$ \\
\hline Does not know & $\mathrm{DA}^{\mathrm{b}}$ & 1,544 & $9.3(7.6-11.3)$ \\
\hline Losartan & C09CA01 & 739 & $4.8(3.8-6.1)$ \\
\hline Simvastatin & C10AA01 & 576 & $4.1(3.5-4.7)$ \\
\hline Omeprazole & A02BC01 & 556 & $3.9(3.5-4.4)$ \\
\hline Hydrochlorothiazide & C03AA03 & 552 & $3.4(2.8-4.3)$ \\
\hline Metformin & A10BA02 & 494 & $3.2(2.7-3.8)$ \\
\hline Captopril & C09AA01 & 424 & $2.8(2.2-3.6)$ \\
\hline Paracetamol & N02BE01 & 439 & $2.8(2.3-3.3)$ \\
\hline Dipyrone & N02BB02 & 378 & $2.4(1.7-3.3)$ \\
\hline Captopril + diuretic & C09BA01 & 309 & $2.4(1.8-3.2)$ \\
\hline Enalapril & C09AA02 & 391 & $2.3(1.9-2.8)$ \\
\hline Atenolol & C07AB03 & 321 & $2.1(1.7-2.8)$ \\
\hline Ibuprofen & M01AE01 & 284 & $2.0(1.5-2.8)$ \\
\hline Fluoxetine & N06AB03 & 244 & $1.9(1.5-2.4)$ \\
\hline Levothyroxine & H03AA01 & 256 & $1.8(1.5-2.2)$ \\
\hline Clonazepam & N03AE01 & 217 & $1.7(1.4-2.1)$ \\
\hline Ferrous sulfate & B03AA07 & 321 & $1.7(1.4-2.1)$ \\
\hline Diclofenac & M01AB05 & 229 & $1.7(1.4-2.0)$ \\
\hline Glibenclamide & A10BB01 & 206 & $1.5(1.2-1.9)$ \\
\hline Acetylsalicylic acid & N02BA01 & 246 & $1.4(1.0-2.0)$ \\
\hline Acetylsalicylic acid (antithrombotic agent) & B01AC06 & 198 & $1.4(1.0-1.9)$ \\
\hline
\end{tabular}

Source: PNAUM - Services, 2015.

${ }^{\mathrm{a}}$ Non-weighted $\mathrm{n}$ value; ${ }^{\mathrm{b}}$ Does not apply 
Table 5. Percentage of patients of the Primary Health Care of the Brazilian Unified Health System that reported having a disease versus use of medicine specific to the disease. National Survey on Access, Use and Promotion of Rational Use of Medicines - Services, 2015.

\begin{tabular}{lcc}
\hline \multirow{2}{*}{ Disease } & \multicolumn{2}{c}{ Report of use of specific medicines for the disease } \\
\cline { 2 - 3 } & $\begin{array}{c}\text { Yes \% } \\
(\mathbf{9 5} \% \mathbf{C I})\end{array}$ & $\begin{array}{c}\text { No \% } \\
(\mathbf{9 5} \% \mathbf{C l})\end{array}$ \\
\hline Hypertension & $77.7(74.3-80.8)$ & $22.3(19.2-25.7)$ \\
Diabetes & $62.1(58.1-65.8)$ & $37.9(34.2-41.9)$ \\
Arthritis, osteoarthritis, rheumatism & $33.1(28.2-38.5)$ & $66.9(61.5-71.8)$ \\
Depression & $32.9(29.4-36.7)$ & $67.1(63.3-70.6)$ \\
Dyslipidemia & $28.7(24.3-33.5)$ & $71.3(66.5-75.7)$ \\
\hline
\end{tabular}

Source: PNAUM - Services, 2015.

\section{DISCUSSION}

Studies of use of medicines enable better knowledge on the characteristics of their users and the identification of factors associated with consumption, contributing to qualify the use and rationalize health resources ${ }^{19}$. Studies with nationwide representative data are scarce $\mathrm{e}^{2,5}$, most being restricted to local research ${ }^{4,13,19}$.

This study was conducted all over Brazil, with a representative sample of patients of PHC, which sought the service for medical care. This characteristic may have influenced some of the results found in this study.

The prevalence of the use of medicines in this study (76.1\%) was higher than those of other studies conducted on $\mathrm{PHC}^{4,9}$ and population-based ${ }^{5,7,10}$.

The prevalence of the use of medicines in individuals in the age group of 65 years or more (92.1\%) was higher than that found in studies conducted with older adults both in $\mathrm{PHC}^{11}$ and in population-based studies ${ }^{20,23}$.

The number of medicines used by patients of PHC ranged from one to 16, a result similar to that observed in other national studies in $\mathrm{PHC}^{25}$ and population-based ${ }^{3}$. The average number of medicines used by individual (2.32) was similar to that observed by the Pan American Health Organization (2005) ${ }^{17}$ and higher than in other Brazilian studies carried out with adults ${ }^{4,71,10,16}$, whose averages ranged from 1.81 to 2.1 , and was also lower than the average found in a study carried out in the primary health care of a district in India $(2.76)^{6}$.

The average number of medicines used increases according to the age group, rising to 3.0 in the group 65 years or more. These results corroborate other national and international studies, ${ }^{37,19,21}$ and are below the average found by Silva et al. (2012) 23 $^{3}$ in a national sample of older adults (3.8) and the 3.7 identified by Rozenfeld et al. (2008) ${ }^{20}$ among retired individuals of Rio de Janeiro. These studies have also associated greater use of medicines with higher level of income. In this study the majority of the population was concentrated on classes C, D and E. The lower participation of people of classes A and B may have contributed to the lower number of used medicines.

The average number of medicines used is an important indicator, which enables the measurement of the degree of polypharmacy of the patient, a predictor factor of medicine interactions and adverse events ${ }^{8}$. The use of multiple medicines is common in older adults due to the higher prevalence of chronic diseases and clinical manifestations resulting from aging. The consumption of medicines in this age group requires greater care, because older adults present physiological changes that affect clinical pharmacokinetics and may generate toxic effects and adverse events ${ }^{22}$. Women typically have greater concern for their health, seeking the health services more frequently, in addition to the existence of several health programs developed for them ${ }^{19}$. In this study, women accounted for the majority of respondents. However, no significant differences were observed in the prevalence of use of medicines among men (74.5\%) and women (76.0\%), in contrast with findings of other studies in which women showed a higher prevalence of use of medicines than men m.5,7,25. $^{3}$ 
We observed a low educational level among medicine users, a result similar to that observed in another national study carried out in $\mathrm{PHC}^{19}$ and different from what was observed in other national population-based studies ${ }^{3,7,20}$. This correlation is troubling, since low educational level can affect the degree of understanding of the prescribed scheme and adherence to treatment. Such differences can be explained by the different characteristics of the evaluated populations.

Among medicine users, $77.6 \%$ had a chronic disease, a result similar to the $77 \%$ found by Carvalho (2005)5. People with chronic diseases seek the services more, and medicines are one of the most used therapeutic interventions? ${ }^{7}$. The high rate of chronic diseases verified in the older adult population and the increased use of medicines in this age group reinforce these findings.

The self-report of use of generic medicines was registered by $57.8 \%$ of medicine users. This data can be due to the change in the legislation that regulates public procurement in Brazil. According to the National Policy of Medicines, promoting the use of generic medicines is a priority guideline. However, despite the compulsory adoption of the generic designation in public purchases and bidding of medicines performed by the Public Administration, according to law 8,666/93, management instances of SUS must purchase medicines at the lowest price, after the technical requirements of the notice are fulfilled. Thus, the medicines provided by SUS may or may not be generic.

When assessing the most used pharmacological groups, painkillers and antipyretics stood out as the main ones, consistent with other national and international studies ${ }^{3,5,21}$. However, when assessed in isolation, it is possible to observe that the medicines that act on the cardiovascular system, particularly antihypertensives, are the most used group. These data are consistent with the demographic transition process experienced by the Country, where the growth of non-communicable chronic diseases is associated with the occurrence of acute conditions still relevant to the health care ${ }^{14}$.

When assessing the 20 most used medicines, seven of them belong to group $\mathrm{C}$ (medicines for the cardiovascular system) and two are antidiabetic (A10 group). There is coherence between the profile of use and the chronic diseases self-referred by patients of PHC of SUS. Like other national studies ${ }^{7,10,20,23}$, hypertension was the most reported disease. This result is consistent with the Brazilian epidemiological profile, in which cardiovascular diseases have high prevalence, including hypertension, especially in the population aged over 65 years ${ }^{5,13}$.

The most used medicine by the population of the study was Losartan (4.8\%), blocker of the AT1 receptor of angiotensin II. In other national studies ${ }^{7,16}$, antihypertensives were also the most used medicines, especially the hydrochlorothiazide diuretic. According to the Brazilian Guidelines of Hypertension ${ }^{24}$ in effect, the pharmacological treatment of hypertension begins with monotherapy, with the AT1 receptor of angiotensin II blocker usually being the prescribed medicine. In the treatment of hypertension, especially in high-risk populations or with cardiovascular comorbidities, AT1 receptor of angiotensin II blockers provide reduction of cardiovascular morbidity and mortality and have a cerebrovascular protective effect superior to other antihypertensives, justifying the growing prescription of this pharmacological class.

We highlight that all the 20 most used medicines by patients of PHC belong to the National List of Medicines in force, being financed by the Basic Component of Pharmaceutical Services and/or provided by the Popular Pharmacy Program. This result suggests that prescribers have used the public medicines lists as guides for prescription within SUS, favoring free access to essential medicines.

Among medicine users, a significant portion (9.3\%) did not know which medicine they were using or for what disease it was prescribed. Although some users reported the reason for which they were using the medicine, as for example "for high blood pressure" or "anti-inflammatory," a large number of people responded "I do not know" or "I do not remember." The low educational level identified especially among older adults (26.5\%), age group that most uses medicines in this study, can justify the results found. This ignorance is 
an important finding, indicating the need for the development of continuous health education strategies, by the multi-professional teams, to contribute to the correct use of medicines.

The prevalence of referred self-medication (38.8\%) was higher than in other national studies $^{2,12}$, being higher in the age group from 18 to 44 years. Economic, political, and cultural factors have contributed to the growth and spread of self-medication in the world, making it a public health problem. According to Arrais $(1997)^{2}$, the inadequate supply of medicines and the non-execution of compulsory submission of medical prescriptions, as well as low education levels, are the most cited reasons for the high frequency of self-medication in Brazil. In this study, previous satisfactory experience with the medicine, the availability of the product at home, and indication by pharmacy professionals were the main reasons for the use of nonprescription medicines.

Regarding the Popular Pharmacy Program, we observed that obtaining medicines from the program is higher as the age group increases. These data are consistent with the profile of medicines provided for free ${ }^{\mathrm{b}}$ by drugstores and pharmacies accredited in the Popular Pharmacy Program, which include medicines for the treatment of chronic non-communicable diseases. Hypertension and diabetes, diseases whose treatments are listed as of free provision of medicines through the Popular Pharmacy Program, were the most referred to by the population aged over 65 years.

In this study, only $10 \%$ of older adults declared they needed help to use the medicines. In general, we also noted that most respondents did not need help to use the medicines, which was also observed in another study with older adults ${ }^{20}$.

This study showed that $78 \%$ of hypertensive respondents used medicines indicated for hypertension, and about $62 \%$ of diabetics used medicines for diabetes. The percentage of individuals who did not use medicines for those diseases can be explained by the deployment of the desirable non-pharmacological interventions for the treatment of these diseases.

However, for dyslipidemia, arthritis, osteoarthritis and rheumatism, and depression, 28.7\%, $33.1 \%$, and $32.9 \%$, respectively, of respondents who reported having these comorbidities used specific medicines to treat them.

One of the limitations of this study is that, being a cross-sectional study, it does not allow the identification of the cause and effect relationship. In addition, a recall period of 30 days was used to evaluate the use of medicines. This criterion may have resulted in some memory bias, which becomes more pronounced the longer the period to be remembered, the age, and the number of medicines used in the period. Patients with hindered access to public health units are not represented as the usage data were obtained from interviews with patients of UBS.

In conclusion, the profile of medicine users verified in this study was composed predominantly by people with low education level and with comorbidities, associated with the identification of a significant percentage of people who did not know the name of the medicines they used. The most used medicines were the antihypertensive ones. Self-medication was higher among young people. Most patients reported to use generic medicines. The average number of medicines and the prevalence of use increased with age. Older patients require special attention and specific actions, as they presented low education level, had less access to consumer goods, reported the presence of more comorbidities and, when compared to other groups, reported difficulties in the use of medicines, which may put them in a situation of greater vulnerability.

\section{REFERENCES}

1. Alvares J, Alves MCGP, Escuder MML, Almeida AM, Izidoro JB, Guerra Junior AA, et al. Pesquisa Nacional sobre Acesso, Utilização e Promoção do Uso Racional de Medicamentos: métodos. Rev Saude Publica. 2017;51 Supl 2:4s. https://doi.org/10.11606/S1518-8787.2017051007027 
2. Arrais PSD, Coelho HLL, Batista MCDS, Carvalho ML, Righi RE, Arnau JM. Perfil da automedicação no Brasil. Rev Saude Publica. 1997;31(1):71-7. https://doi.org/10.1590/S0034-89101997000100010

3. Bertoldi AD, Barros AJD, Hallal PC, Lima RC. Utilização de medicamentos em adultos: prevalência e determinantes individuais. Rev Saude Publica. 2004;38(2):228-38. https://doi.org/10.1590/S0034-89102004000200012

4. Bertoldi AD, Barros AJ, Wagner A, Ross-Degnan D, Hallal PC. Medicine access and population covered by primary health care in Brazil. Health Policy. 2009;89(3):295-302. https://doi.org/10.1016/j.healthpol.2008.07.001

5. Carvalho MF, Pascom ARP, Souza-Junior PRB, Damacena GN, Szwarcwald CL. Utilization of medicines by the Brazilian population, 2003. Cad Saude Publica. 2005;21 Supl 1:S100-8. https://doi.org/10.1590/S0102-311X2005000700011

6. Costa A, Bhartiya S, Eltayb A, Nandeswar S, Diwan VK. Patterns of drug use in the public sector primary health centers of Bhopal district. Pharm World Sci. 2008;30(5):584-9. https://doi.org/10.1007/s11096-008-9215-6

7. Costa KS, Barros MBA, Francisco PMSB, Cesar CLG, Goldbaum, Carandina L. Utilização de medicamentos e fatores associados: um estudo de base populacional no Município de Campinas, São Paulo, Brasil. Cad Saude Publica. 2011;27(4):649-58. https://doi.org/10.1590/S0102-311X2011000400004 8

8. Farias AD, Cardoso MAA, Medeiros ACD, Belem LF, Simoes MOS. Indicadores de prescrição medica nas unidades básicas de Saúde da Família no município de Campina Grande, PB. Rev Bras Epidemiol. 2007;10(2):149-56. https://doi.org/10.1590/S1415-790X2007000200003

9. Fleith VD, Figueiredo MA, Figueiredo KFLRO, Moura EC. Perfil de utilização de medicamentos em usuários da rede básica de saúde de Lorena, SP. Cienc Saude Coletiva. 2008;13 Supl:755-62. https://doi.org/10.1590/S1413-81232008000700026

10. Galvao TF, Silva MT, Gross R, Pereira MG. Medication use in adults living in Brasilia, Brazil: a cross-sectional, population-based study. Pharmacoepidemiol Drug Saf. 2014;23(5):507-14. https://doi.org/10.1002/pds.3583

11. Goulart LS, Carvalho AC, Lima JC, Pedrosa JM, Lemos PL, Oliveira RB. Consumo de medicamentos por idosos de uma Unidade Básica de Saúde de Rondonópolis/MT. Estud Interdiscip/ Envelhec. 2014 [cited 2016 Mar 4];19(1):79-94. Available from: http://www.seer. ufrgs.br/index.php/RevEnvelhecer/article/view/25854/31002

12. Loyola Filho AI, Uchoa E, Guerra HL, Firmo JOA, Lima-Costa MF. Prevalência e fatores associados a automedicação: resultados do projeto Bambui. Rev Saude Publica. 2002;36(1):55-62. https://doi.org/10.1590/S0034-89102002000100009

13. Loyola Filho AI, Uchoa E, Firmo JOA, Lima-Costa MF. Estudo de base populacional sobre o consumo de medicamentos entre idosos: Projeto Bambuí. Cad Saude Publica. 2005;21(2):545-53. https://doi.org/10.1590/S0102-311X2005000200021

14. Mendes EV. As redes de atenção a saúde. 2. ed. Brasília (DF): Organização Pan-Americana da Saúde; 2011.

15. Oliveira LCF, Assis MMA, Barboni AR. Assistência Farmacêutica no Sistema Único de Saúde: da Política Nacional de Medicamentos a Atenção Básica a Saúde. Cienc Saude Coletiva. 2010;15 Supl 3:3561-7. https://doi.org/10.1590/S1413-81232010000900031

16. Oliveira NSC, Xavier RMF, Araújo PS. Análise do perfil de utilização de medicamentos em uma unidade de saúde da família, Salvador, Bahia. Rev Cienc Farm Basica Apl. 2012 [cited 2016 Mar 4];33(2):283-9. Available from: http://serv-bib.fcfar.unesp.br/seer/index. php/Cien_Farm/article/ view/2051/1245

17. Organização Pan-Americana da Saúde. Avaliação da Assistência Farmacêutica no Brasil: estrutura, processo e resultados. Brasília (DF): OPAS: Ministério da Saúde; 2005 [cited 2016 Mar 4]. (Série Medicamentos e Outros Insumos Essenciais para a Saúde). Available from: http://bvsms.saude.gov. br/bvs/publicacoes/avaliacao_assistencia_farmaceutica_estrutura_resultados.pdf

18. Osorio de Castro CGS, coordenadora. Estudos de utilização de medicamentos: noções básicas. Rio de Janeiro: Editora FIOCRUZ; 2000.

19. Pereira VOM, Acurcio FA, Guerra Junior AA, Silva GD, Cherchiglia ML. Perfil de utilização de medicamentos por indivíduos com hipertensão arterial e diabetes mellitus em municípios da Rede Farmácia de Minas. Cad Saude Publica. 2012;28(8):1546-58. https://doi.org/10.1590/S0102-311X2012000800013 
20. Rozenfeld S, Fonseca, MJM, Acurcio FA. Drug utilization and polypharmacy among the elderly: a survey in Rio de Janeiro City, Brazil. Rev Panam Salud Publica. 2008:23(1):34-43. https://doi.org/10.1590/S1020-49892008000100005

21. Sans S, Paluzie G, Puig T, Balañá L, Balaguer-Vintró I. Prevalencia del consumo de medicamentos en la población adulta de Cataluña. Gac Sanit. 2002 [cited 2016 Mar 4];16(2):121-30. Available from: http://scielo.isciii.es/pdf/gs/v16n2/v16n2a02.pdf

22. Secoli SR. Polifarmácia: interacões e reações adversas no uso de medicamentos por idosos. Rev Bras Enferm. 2010;63(1):136-40. https://doi.org/10.1590/S0034-71672010000100023

23. Silva $\mathrm{AL}$, Ribeiro $\mathrm{AQ}$, Klein $\mathrm{CH}$, Acurcio FA. Utilização de medicamentos por idosos brasileiros, de acordo com a faixa etária: um inquérito postal. Cad Saude Publica. 2012;28(6):1033-45. https://doi.org/10.1590/S0102-311X2012000600003

24. Sociedade Brasileira de Cardiologia; Sociedade Brasileira de Hipertensão; Sociedade Brasileira de Nefrologia. VI Diretrizes Brasileiras de Hipertensão. Arq Bras Cardiol. 2010;95(1 Supl 1):1-51. https://doi.org/10.1590/S0066-782X2010001700001

25. Vosgerau MZS, Soares DA, Souza RKT, Matsuo T, Carvalho GS. Consumo de medicamentos entre adultos na área de abrangência de uma Unidade de Saúde da Família. Cienc Saude Coletiva. 2011;16 Supl 1:1629-38. https://dx.doi.org/10.1590/S1413-81232011000700099

26. WHO Collaborating Centre for Drugs Statistics Methodology. Anatomical Therapeutic Chemical Classification - ATC Code. Oslo; 2016 [cited 2016 Feb 10]. Available from: http://www.whocc. no/atc_ddd_index/.

Funding: Department for Pharmaceutical Services and Strategic Health Supplies and Department of Science and Technology of the Secretariat of Science, Technology and Strategic Supplies of the Brazilian Ministry of Health (SCTIE/MS - Process 25000.111834/2, Decentralization of FNS Resources).

Authors' Contribution: Conception and design of the study:JA, MRS, AAGJ, EAC, FAA, IAG, KSC, MGOK, OMS, SNL. Analysis and interpretation of data: CMFNC, MRS, JA, RCRMN, VEA. Elaboration of the draft or critical review of the content: CMFNC, MRS, JA, RCRMN, VEA. Approval of the final version of the manuscript: MRS, JA, RCRMN, VEA, AAGJ, FAA. All authors are able to take public responsibility for the published work and have full confidence in the accuracy and integrity of the work.

Conflict of Interest: The authors declare no conflict of interest. 